\title{
Bilingual Panama: EFL Teacher Perceptions, Study Abroad in an Immersion Environment
}

\author{
Dalys Vargas \\ English Department, Quality Leadership University, Republic of Panama
}

\begin{abstract}
In 2014, the newly inaugurated Government of Panama launched the Panamá Bilingüe initiative, considering that sustainable development demanded taking emergency measures to improve the teaching of English in public schools. The program is designed to impact at least 250,000 students in a five-year period, gradually training approximately ten thousand pre-service and experienced English teachers. Using a narrative inquiry method, twelve teachers who sojourned for eight weeks in the United States, England, and Scotland under the program were interviewed after their return, to study their perceptions of the benefits and challenges of cultural and linguistic immersion on EFL teacher development, and how it specifically affected their teaching skills. The teachers appreciated practicing English in an immersion environment, learned new teaching techniques, and reflected on their prior knowledge and practices. Nevertheless, they felt that the ESL approach prevalent at the host universities responds to needs that differ from those they deal with in Panama, where the low proficiency of primary school teachers and inadequate school facilities are major obstacles to teaching and learning English.
\end{abstract}

Index Terms-bilingualism, EFL pedagogy, EFL teacher training and development, English proficiency of EFL teachers, language policy, narrative inquiry

\section{INTRODUCTION}

The EF English Proficiency Index (EF Education First, 2014) ranked Panama, in 2013, in position 56 of a total of 60 countries evaluated to determine the average level of English skills among adults. Panamanian Government authorities were alarmed. Incredibly, Panama, with a service-driven economy powered by world trade, had ranked below Ecuador, Guatemala, and El Salvador.

Having a population of only four million, Panama has one of the most prosperous economies in Latin America. However, the distribution of wealth in the country is also one of the most unequal in the region (United Nations, Panama, 2016). Students who can attend the relatively expensive private schools have been fortunate to acquire at least an intermediate, "working knowledge" of English, while large segments of the population are deprived of the advantages of mastering the world's lingua franca.

The Panamá Bilingüe initiative, personally set in motion by the President of Panama, intends to "provide training in bilingual education to about 2,000 teachers every year, at the same time preparing 20,000 high school students and 30,000 elementary school students [annually, over a period of five years], with the objective of enabling more Panamanians to have access to the best jobs" (Government of Panama, Ministry of Education, 2014). The project has three components, which are being implemented in a growing number of schools. An After-School program, for high school students, and a Kids program, for elementary school students, offer youngsters additional hours of exposure to the English language. Under Teacher Training, novice and in-service English teachers are being placed in colleges and universities in the United States, Canada, the United Kingdom, and Barbados to strengthen their knowledge of English and their teaching skills in an English-speaking immersion environment, aiming "to improve the teaching of oral and written English", according to Executive Decree 148 of April 1, 2016 (Government of Panama, Ministry of the Presidency, 2016). Article 5, point 2(a) of the decree establishes that

Once the teachers return to the country, having satisfactorily completed the international phase of their training, they will be coached for a year, during which they must participate in a two hundred [200]-hour program leading to an international certification exam, according to the specific area in which they work. This must be a CELTA (Certificate of English Language Teaching) ... or equivalent, TKT (Teaching Knowledge Test) or equivalent.

The Gabriel Lewis Galindo Foundation and several external Second Language Acquisition consultants have been playing a major role in carrying out the Panama Bilingüe program. The U.S. Department of State has lent its support in different ways: A U.S. Government-funded Teacher Match program would send a number of U.S. English teachers to Panama to be matched with Panamanian public middle or high school English teachers, to assist in classroom instruction and curriculum development (U.S. Embassy, Panama, 2014). "Teacher training focused on TESOL best practices, including the Sheltered Instruction Observation Protocol (SIOP) Model" is being facilitated, and an English Language Fellow will "review Panama Bilingue strategy and give feedback accordingly, as well as observe classes and provide peer counseling and peer mentoring to Panama Bilingue teachers" (U.S. Department of State, 2015-2016). The Department of State Regional English Language Officer set up his office in Panama, a presence described by the U.S. 
Embassy as a resource in support of the Panamá Bilingüe program (U.S. Embassy, Panama, 2015). The collaboration of the Fulbright Scholar Program (Fulbright Scholar Program, Panama, n.d., ca. 2015) was also offered.

Panamá Bilingüe is being implemented in a country that is proud of having ended the existence of the Canal Zone, a U.S. colony in its midst, when the Torrijos-Carter Treaties were signed in 1977. Panamanians thereby gained control of the Panama Canal, today a vital source of revenue. In the past, many people in Panama deliberately chose not to learn English, as a way to protect national identity from cultural assimilation, rejecting ideological submission. Psychological resistance to acquiring the language still lingers, stoked by the horrors of the 1989 U.S. invasion of Panama. Teachers who traveled abroad under Panamá Bilingüe spontaneously displayed Panamanian flags, folkloric outfits, traditional jewelry and other symbols of identity and loyalty to their homeland at the airports and on college and university campuses.

\section{LITERATURE REVIEW}

In the field of second language acquisition, the term “immersion" originated in Canada in the 1960's, when Englishspeaking students learned in an experimental program where French was used as the medium of instruction. However, the term has been used to describe a variety of language learning experiences. Johnson \& Swain (1997) identified eight core features of immersion and offered a good look at specific language-learning projects carried out in different countries with diverse approaches, all of them labeled "immersion". Swain \& Lapkin (2005) reviewed the mentioned core features, realizing that changes in the sociopolitical realities of Canada (among them, the increase in ethnic diversity), and new research, required updating the pedagogy (p. 170).

Harvey, Roskvist, Corder, \& Stacey (2011) describe "different arrangements [that] enable language teachers to spend varying amounts of time in a country where their teaching language is used as a first language. Sojourns range from two weeks to one year" (p. 5). It is in this sense that the concept "immersion" is used in this paper.

Lee $(2009$, p. 1095) is optimistic about short study-abroad immersion programs for English teachers, pointing out that 'the literature suggests that overseas teaching experiences for student teachers' [sic] result in personal growth, a broadened world view and increased professional competence (e.g. Barkhuizen \& Feryok, 2006; Stochowski \& Chleb, 1998; Tang \& Choi, 2004; Ward \& Ward, 2003; Willard-Holt, 2001)".

However, Roskvist, Harvey, Corder, \& Stacey (2014, p. 324) wrote that "There is very limited research focusing on in-service language teachers undertaking immersion or SA [study abroad] programmes (Harbon 2007; Wernicke 2010; Gleeson \& Tait 2012)"'. Wang (2014, p. 71) echoed these words, noting that, whereas the bulk of research on the study abroad of English involves undergraduate students, few studies have been conducted on experienced teachers of English as a Foreign Language (EFL).

The pertinence of studying language teachers' perceptions of the training and development they are required to undergo, or personally decide to take, is clearly demonstrated by Freeman (1989), in an enlightening article on how classroom practice and student learning outcomes depend on decisions made by the teachers based on their knowledge, skills, attitudes, and awareness. According to S. Borg (2015a), whose main area of research in TESOL has been teacher cognition, his work now concentrating on professional development for English language teachers,

The major justification for studying L2 teachers' beliefs is that they provide insight into the psychological context for teaching and teacher learning which can inform the design of initiatives which encourage teachers to learn, change or behave in particular ways. (p. 500)

Johnson and Golombek (2011) point to the fruitfulness of narrative inquiry, maintaining that "the transformative power of narrative lies in its ability to ignite cognitive processes that can foster teacher professional development" ( $\mathrm{p}$. 504). These authors claim that productive changes have been seen to occur in classroom practice as a result of the teachers' externalization, verbalization, and systematic examination [emphasis added] of their experiences, and that "narrative as a vehicle for teacher inquiry has become the primary means by which researchers have come to understand and document teachers' professional development" (p. 488).

\section{METHODS}

\section{A. Research Design}

The research design for this project, based on narrative inquiry, using a qualitative, inductive approach, was guided by Phakiti \& Paltridge (2015), Barkhuizen (2015), Borg (2015, a \& b) and Holliday (2015).

\section{B. Participants}

Oral accounts were obtained in face-to-face interviews with twelve experienced Panamanian EFL teachers working in the public school system who had been sent to the United States, England and Scotland. Six had gone to the U.S. and six to the U.K. Teachers placed in Canada were not interviewed because a list of the teachers and their destinations was not made available. Eleven of the teachers work in high schools, four of them in a teacher training institute. Five of the participants also teach in public universities, one in a private university, and one both in a private and a public university. Only one of the teachers works in a primary school. Two of the teachers hold an MA-TESOL degree; two obtained an MA in Linguistics; one has an MA in Applied Linguistics; one has an MA in English. In other words, half 
of the teachers interviewed had what appeared to be a strong knowledge base in English and English teaching. By contrast, the elementary school teacher, whose workplace was a rural school, was struggling to finish a BA in English and had a very low proficiency.

It can be argued that this small group of teachers is not a truly representative sample, since most had at least an intermediate command of English and had already received higher education in English teaching methodologies. However, this background made them, potentially, a more reflective group, able to engage in a refined metacognitive processing of their study-abroad experience. They will probably be called upon to become teacher trainers in the PB program, according to the plan outlined in Executive Decree 148 of April 1, 2016.

\section{Procedure}

Ten of the teachers were interviewed in their workplace. Each one was interviewed separately. They were asked to bring with them photos, handouts, other documents and feedback furnished to them during their experience, as well as personal diaries and other records, for the purpose of helping to transport them back to the environment of their studyabroad sojourn. All of them chose to be interviewed in English.

A letter was sent to the principals/headmasters of the two institutions where most of the teachers work, asking for permission to carry out the interviews, as required by their school policies. An informed consent form was signed by each teacher and the researcher before starting the interview, setting forth in writing that the identities of the participants would be kept anonymous.

Before and after each interview, journal entries were made to record conditions of the interaction and other observations. The interview questions, inspired by Borg (2015b, p. 544), were written in advance, and the participants were not exposed to them before the interview, to avoid the preparation of "the right answers". The questions served as a starting point and were returned to after listening to what the teachers had to say. The interviews were audio recorded. The researcher took verbatim and other notes while they were carried out. Each interview was transcribed.

\section{Analysis}

The thematic analysis of the data followed the four steps outlined by Holliday (2015, pp. 53-54): (1) coding, i.e., converting the data to key words and phrases; (2) determining themes; (3) classifying the themes into headings and subheadings to build an argument, and (4) going back to the data, collecting extracts to support the argument, reassessing the codes and themes, drafting and redrafting results.

During the whole research process, Phakiti \& Paltridge's (2015) view that "qualitative researchers allow themselves to be involved in formulating meanings and interpretations of what they have observed" (p.13) was reassuring. The coconstruction of meaning, learning and knowledge by the researcher and each participant, considered inevitable by Barkhuizen (2015, p. 174), occurred when questions were made to elicit ideas that the participants might find it difficult to articulate (Borg, 2015a, pp. 492-493). However, the report of findings and conclusions is carefully mindful of Holliday's (2015) warning that the researcher should heed "the moral imperative embedded in how we should deal with data - taking disciplined care to refrain from imposing meaning [emphasis added], not only on data, but also on the people who it represents" (p. 60).

\section{RESULTS}

The universities and colleges that hosted the interviewed teachers in 2015 and 2016 had the liberty of proposing the organization and the specific contents of the eight-week study abroad period. However, they had in common an objectives- and task-based, student-centered Communicative Language Teaching approach, endeavoring to achieve the two main objectives with which they were entrusted: (1) improving the teachers' knowledge of and proficiency in English and (2) equipping them with effective English teaching techniques. In addition to reviewing English language skills, discussing language teaching methods, practice activities and reflections in class, visits were organized to schools, where the teachers watched real-life language classes. In some cases, they even had the opportunity to make a presentation to the students. The teachers were also taken on tours to places of cultural interest.

There were different accommodation arrangements. Some of the teachers stayed with families, enjoying additional opportunities to practice the language, while others shared rooms in college dormitories. One shared an apartment, and another stayed at a youth center.

The perceptions of the teachers have been grouped below under the headings "Benefits" and "Challenges". Representative extracts from the interviews illustrate the respondents' thoughts. Pseudonyms are used in lieu of the participants' real names.

\section{A. Benefits}

\section{1. "You are forced to use the language".}

Alberto: You are surrounded by, you know, the English speakers and, obviously, you have to put in practice all your knowledge and all the words, the phrases, the sentences, the pronunciation, and everything that you have learned during the years... 
2. Enhancement of teaching skills by learning methods and strategies. All the teachers reported having learned useful techniques, sometimes revisiting specific skills and strategies they had been exposed to before their immersion experience, among them:

Relying less on memorization; instead, "looking for those things that our teenagers are interested in", such as listening to music, watching a video, and carrying out more computer-assisted activities, when possible.

Motivating students by asking them what they would like to learn, and rewarding them when they do a good job.

Thinking of the students' needs. In the case of technical and trade schools, providing students with English for Specific Purposes, in addition to basic knowledge of the language for communication purposes.

"Not giving so many written tests"; greater emphasis on listening and speaking. Instead of the usual concentration on grammar rules and grammatical structures, have more conversation, more oral exercises; for example, silent listening, followed by oral production.

Simpler lesson planning, concentrating on fewer topics and objectives in a class.

Improving pronunciation by learning to listen and to observe carefully, breaking down words into sounds, paying attention to mouth and lip movements and the position of the tongue, then practicing with phrases and sentences, noticing where the stress should go; use of phonetic charts.

Different forms of student interaction: mingling, pair and group work, in some cases including physical rotation and changes of location in class, to complete reading, writing, and oral tasks; for example, "work stations", and jigsaw creation of tests and exercises.

Classroom management.

Increasing the use of visuals; for example, to introduce lessons.

Teaching reading strategies, such as getting meaning from context, without stopping so often to consult with a dictionary.

Using rubrics for a more objective evaluation of learning, thereby motivating students to do their best by knowing what they are expected to achieve and how they will be assessed.

3. English language proficiency improvement.

Yvonne: In each group, we had high level students and low level students, so the proficiency level were [sic] not the same ... But we noticed improvement during the training ... We helped them to survive ... They improved very much.

4. Reflection on prior teaching practices; reinforcement of prior knowledge. The methods and skills discussed and demonstrated during their study abroad were already known to some of the teachers; however, they valued reviewing them. We must remember that most of the teachers interviewed were qualified professionals.

Carmen: It was like reinforcement, most of all, [of] what I learned at the university...

Giselle: It helped me to think a lot, because I try to compare the way we teach here in Panama and what they were teaching there, and also to see what we can improve in order to take advantage of what we were doing there ... But most of the time, their way of teaching was similar to our way of teaching. It wasn't so different. The only thing is that they have more technology.

Yolanda: The classes [were] very similar as we do here in Panama, but with the elements needed for the performance of that: the infrastructure, the materials and the organization. When I witnessed the classes, I said: "I would do it in a different way", [or] "I would do it the same way". So I said: "Wow! The only thing I need in Panama is they have a permanent classroom."

Kiara: I have been teaching for eight years ... With Panama Bilingüe, I had the opportunity to update my knowledge; also, [to] reflect about why I do this this way, or maybe there's a different way to do this.

\section{Awareness of the need to improve English teaching capability.}

Yolanda: We noticed that -wow!- we Panamanians have a lot of gaps, and we have a lot of things to learn.... We have to demand more from ourselves ... One person told me: "Yolanda, I have to be honest to myself, haven't done too much for myself. I have a diploma, I'm working in MEDUCA [Ministry of Education], it's a permanent job, but I haven't done [enough] because I am feeling frustrated, I cannot understand the teachers, they're speaking too fast."

6. Motivation to improve professionally.

Ariel: Now I feel more motivated, and now I can tell my students the importance of learning English ... not only for traveling, but for many other things, like reading a good book, or watching any documentary in English ..., and I try to transmit my motivation to my students.

Dana: I like to improve myself. And this opportunity, [with] Panama Bilingüe, has been a very good one. Being there, with the immersion. Not just me ... It has been a very, very good experience.

7. The opportunity to visit and experience an English-speaking country. The teachers had fun visiting places of cultural and historical interest, and these experiences put them in contact with authentic uses of English and promoted intercultural communication.

Alberto: I'm very happy with the initiative of Panama Bilingüe. It's a very interesting, very useful strategy by MEDUCA and the Lewis Galindo Foundation also ... I have heard of some teachers who have not had that experience, to be in a country where English is spoken. 
Jason: [Pointing to a picture:] This is Rosslyn Chapel, I think ... We had the tours, not to visit schools, but just for fun .... Being in another country ... was a very enriching experience, because not only did I learn from teachers, but I learned new things from real people. I went to the places to meet the people, and talk to the people, and listen to them ...

Kiara: We had the opportunity to interact with the students at the university, and also we visited London and the Buckingham Palace. We saw that, in order to introduce us to the culture .... We had the opportunity to visit Oxford, too.

Yvonne: When I visit[ed] the museums, when I went to the different places, and I read the different scriptures [sic; labels, written explanations] they have on the monuments, ... the most amazing story was when they taught about the American Indians and how they were forced to do things to change their ideology, their ideas, their culture, and how the American government ... forced them to go to the war, ... when Vietnam. And also the Civil War ... We went to the American Indian Museum. It's just like Victoriano Lorenzo here ...

8. Awareness of different varieties of English.

Lorenzo: I would say "Let me help you with the garbage." They would say "That's American. You have to say "rubbish".

\section{Professional and personal, intercultural relationships.}

Bruno: Just sharing with other people, with other cultures, it's already an advantage.

Dana: This was professor [name withheld] ... He came to Panama .... We invited [him], and he came to Panama to talk to the Minister of Education.

Yvonne: I'm in contact with her [the professor] ... she's really fantastic. And she said: "Hey, if you come to [a particular State in the U.S.], you have to visit me!"

The teachers did not agree unanimously on the benefits of their study-abroad experience. For example, while Kiara welcomed participating in student-centered activities (as a teacher student), Lorenzo had a completely different view, preferring the teacher-centered approach. He also suggested that the teacher training goals of the Panamá Bilingüe Program can be met in Panama, without having to travel abroad:

Lorenzo: The only thing that I didn't like is that we had to give classes for members of the group from Panama .... Because I think that, if we go there, it's to learn [from] the professor from England. Because to go there, taking nine, ten hours [flight duration], it's better to stay in Panama and to be with people here, and we are going to learn from each other. We don't have to travel to England.

\section{B. Challenges}

1. Limited English proficiency, especially of elementary school teachers. The teachers agreed that eight weeks in an English-speaking country may help in different ways to improve linguistic skills and the ability to manage some aspects of language learning in class, but they believed that a much longer period of study is needed for most of the Panamanian EFL elementary school teachers to acquire the knowledge of English and the proficiency level indispensable to teach English well. One of the teachers passionately expressed the view that the best way to promote the learning of English in Panama is to begin teaching content areas such as Mathematics, Science and Social Studies in English at an early age, with the caveat that the Social Studies classes should be based on books written by Panamanian authors.

Ariel: We needed more ..., not methodology, I think, but more English ... There should be more coordination between MEDUCA and ... the universities in those countries where they're sending teachers.

Carmen: From the 24 [Panamanian EFL teachers participating in her group], three or four ... were teenagers, and the rest were [practicing] teachers. I think that ... their level of teaching was ... elemental .... As soon as they [the host universities] realized that most of us were elementary school teachers, they lowered the level.

Yolanda: And they speak very fast ... Some classmates of mine, they feel [felt] frustrated ... [Some colleagues would say] "I don't understand when they are speaking in English." .... Why don't we go to the elementary schools [in Panama], in which the teachers must be well, well trained? You have to really make sure that the teacher commands the language. If she doesn't, the students, who are very [much] like a sponge, they are very receptive, they won't learn well...

\section{Following speech in different varieties of English.}

Jason: They spoke English, but the Scottish dialect. And sometimes you had to ask them again, because it was, sometimes, difficult. They have different vowel patterns, and different words, also ...

3. Age.

Alberto: We were too many people. We were with two old teachers, almost sixty-nine years old. It was very embarrassing for us, because ... You know, some things, like walking fast, taking a metro, taking a taxi, taking the airplane. The problem was that we were the first group, so there was [sic] no rules.

\section{Very hard work!}

Yvonne: They were very demanding. The only thing people were complaining about was too much hard work. Because, during the storm, we ... were isolated ... During those days, we had a lot of homework, because we couldn't go to the university, so they said homework, homework, homework.

5. The teaching was aimed at acquisition of English in an ESL setting, but in Panama we are in an EFL setting. 
Jason: I think that was one of my main complaints. ... Many things that I was learning there wouldn't apply to teaching in Panama. The main reason for that is that in Panama we teach what we call EFL, and the setting is completely different from what they teach there, and everything that we learned there was aimed at ESL.

Lorenzo: I went to [an] elementary school twice and to a high school one time ... The majority [of the students] were from Pakistan.

\section{The need to make adaptations for application in Panama.}

Lorenzo: There are lesson plans for one thing, but it doesn't work for us here in Panama.

Yolanda: How we can do it in Panama? Because we have many different things against, that we have to try make adaptations, we cannot follow exactly as we learned it there.

\section{Classroom arrangement.}

Carmen: Their classrooms are completely different to us [from ours]: ... Good for teaching! ... Even the position of the chairs, in front of the teacher, some of them around the teacher ... And sometimes we can't do that in here, because we do not have time enough if you start arranging everything ...

Yolanda: The government has invested a lot of money in this program ... I suggest that every single teacher of English must have a permanent classroom... I have six groups in this school. I have to go with my material ... group by group [to different classrooms]. I have to take it all the time ... That's not good!

8. Number of groups assigned to each teacher, and number of students in each classroom.

Yolanda: Teachers [in the place she visited in the United States] have maybe like two groups, whereas, in Panama, teachers have like six groups ... In most of the schools [in Panama], classes have 44 students, 39 ... They couldn't imagine how a teacher, how a government or society can cope with stress, ... and also how the society says "People are not speaking English!” How [can they]?

\section{Resources.}

Ariel: Yes, ... the cultural shock, technology. Rooms [in the immersion experience] were more equipped for teaching; you have a projector already there ..., and good Internet connections. Everything was there. Libraries. So I was comparing [with] the place where I studied here, in Panama City, or my school. We don't have a dictionary to look at. Teachers [there] have tools, all the tools they need. And the school, for example, that we visited ... everything was there, just ready to be used. I think that that is what we are lacking here .... OK, you can receive methodology and good information. But I think also with tools ... We need more language labs, and headphones, because, for example, in my case, I like phonetics, for my students to learn English sounds. It's impossible here ... We have the facilities; they should be equipped with technology in order to reach our students' expectations. And that is quality. Also, books for the students, because we don't have any textbooks. They can't take home, for example, ... a workbook.

The infrastructure, technology and materials available at the countries they visited impressed the teachers, producing a strong demonstration effect. A remarkable example of the very different conditions in which they have to work is the language lab of a high school where four of the teachers were interviewed. The laptops used by the students were kept in a cabinet under lock and key, to be taken out at the beginning of the day and stored away after the final class. That particular room did not have access to the Internet.

It should be noted that one of the universities that hosted Panamanian EFL teachers advised making the best of the resources available, however limited, indicating that good English teaching can be achieved in the absence of state-ofthe-art technology.

In a rural high school where four of the interviews were conducted, the students worked in class and did their homework using photocopies provided by the teacher from his personal budget. Markers, paper, and other supplies were also purchased by the teacher from his own pocket.

\section{DISCUSSION}

The teachers' oral accounts, and existing research, suggest that the Panamá Bilinguie program cannot be expected to automatically lead to better teaching and improve student learning outcomes on the national level as soon as the teachers return to their posts after the study abroad period or shortly thereafter. Explaining the difference between training and development, Freeman (1989) soberly cautions against the "misconception ... that transmission of knowledge will lead to effective practice" (p. 29). He clarifies that changes in performance are measurable after teacher training, which involves "the mastery of discrete skills and knowledge" that can be taught to the teacher directly, whereas teacher development is a different strategy, triggering internal processes that produce an increased awareness by the teacher of her/his own classroom practice, i.e., what she/he is doing and why, which is what really makes a difference in teaching outcomes. Therefore, changes may not be immediately observable and cannot be expected to occur within a designated period of time (pp. 39-43).

The above is especially significant in relation to the number of primary school teachers in Panama having a very low level of proficiency in English. Richards, Conway, Roskvist, \& Harvey (2013) point out that "rather than learning the language for a minimum length of time, teachers need to be learning the language until they have a high level of proficiency. As this level may not be reached by teachers during the [immersion] course, facility needs to be available for them to continue to study the TL [target language] post-course" (p. 244), because "commitment to building teachers' 
language proficiency is a long-term investment, as it is well known that learning language is a developmental process (Crabbe, 2005) and becoming proficient in another language takes time" (p. 245).

Different factors need to be considered to decide the course of action to take and estimate the time required to improve English language teaching and learning in "Periphery" countries such as Panama. As emphasized by B. Kumaravadivelu (2001), developing a meaningful language pedagogy demands recognizing particularity. Local conditions should determine, for example, whether English is to be taught mainly for everyday communicative purposes or for academic purposes, such as preparing for higher education in an English-speaking country. There can be a lack of motivation in particular groups of students to make the effort required to learn the language; few opportunities exist to interact in English, inside and outside the classroom; and teachers often have to perform their work in challenging circumstances, with large numbers of students in class and limited resources. A particular reality that must be taken into account is hinted at by Yvonne: The mother tongue (L1) that many students from the indigenous communities of Panama bring to class, along with their own cultural perspectives, is not Spanish, so English would be their L3, and sometimes their L4.

In line with Jason and Lorenzo's comments, Liu (1999) was highly critical of teacher training and development programs in English-speaking countries. As reviewed by Bame (2001),

Dilin Liu argues that NNS [non-native speaker] teacher trainees' needs are not being met in the North American, British, and Australian (NABA) teacher training contexts. He argues that L2 acquisition theories and TESOL methodologies are based on data from immigrants and L2 students in NABA countries. He further states that these are not suitable to most of the NNS teacher trainees' situations. (R-9)

From a different position, the benefits of linguistic and cultural immersion in an English-speaking environment are upheld by G. Braine (2005, p. 15), citing Reeves \& Medgyes' (1994) suggestion that "frequent exposure to authentic native language environments and proficiency-oriented in-service training activities" may help "non-native" speaker teachers deal with their language difficulties.

Braine adds extremely important advice: "Further, in order to enhance the self-perception of these teachers, they should be made aware of their advantageous condition as language teachers" (p. 15). The nature of the mentioned advantageous condition was set forth convincingly by Edge (1988) and Medgyes (1999), the latter establishing the often-cited position that

NNS teachers can:

- provide a good learner model for imitation,

- teach language learning strategies more effectively,

- supply learners with more information about the English language,

- anticipate and prevent language difficulties better,

- be more empathetic to the needs and problems of learners, and

- make use of the learners' mother tongue (p. 178)

Yes, use of the mother tongue, so controversial in the context of EFL teaching in Panama, where using "English only" has been established as one of the highest services a teacher can provide to her/his students! "Research suggests that allowing a judicious use of the L1 on the part of learners may be warranted", indicated Swain \& Lapkin (2005, pp. 169 \& 179-180), mentioning studies by Villamil \& de Guerrero (1996), Behan \& Turnbull (1997), and Antón \& DiCamilla (1998).

The advantages of sharing the culture and language of the students, so valuable for our EFL teachers' awareness of their own potential, at the same time brings up the recurrent discussion regarding the use of the native speaker/nonnative speaker (NS/NNS) labels and mindsets in teacher development and training activities. The significance and implications of the strengths listed by Medgyes are extraordinary for teachers whose level of language proficiency, strong "foreign" accent, and different cultural approaches to teaching English may seem to make them unfit to effectively perform their job; however, the words are headed by the non-native speaker label which Medgyes considered reasonable to keep but is so questionable (as in Paikeday, 1985; Edge, 1988; Phillipson, 1992; Davies, 2003) Readers wishing to view work reflecting the uncompromising rejection of the native/non-native distinction are hereby referred to Swan, Aboshiha \& Holliday (2015); Holliday (2014), Shin (2007), and McKay (2003).

Regarding knowledge of the language, the need to include a "language development provision in teacher training curricula" (Murdoch, 1994) has been recognized and confirmed by research -and common sense- over time, as substantiated by Cullen (1994) and Frazier \& Phillabaum (2012, p. 173), the latter pointing to the work of Barratt (2010), Kamhi-Stein (1999), Lee (2004), Liu (1999), and Nemtchinova, Mahboob, Eslami \& Seran (2010). J. C. Richards (2011) has summed up the discussion on "the language proficiency factor" as follows:

Most of the world's English teachers are not native speakers of English and it is not necessary to have a native-like command of a language in order to teach it well (Canagarajah, 1999). The issue is, how much of a language does one need to know to be able to teach it effectively and how does proficiency in a language interact with other aspects of teaching (Bailey, 2006; Kamhi-Stein, 2009)? To answer these questions it is necessary to consider the language-specific competencies a language teacher needs in order to teach effectively. These include the ability to provide good language models, to maintain use of the target language in the classroom, to give correct feedback on learner language, and to provide input at an appropriate level of difficulty [emphasis added]. Learning how to carry out 
these aspects of a lesson fluently in English is an important dimension of teacher-learning for those whose mother tongue is not English. There appears to be a threshold language proficiency level a teacher needs to have reached in the target language in order to be able to teach effectively. (p. 3)

According to H. Richards, Conway, Roskvist, \& Harvey (2013, p. 237), citing Farrell \& J. C. Richards (2007), the "language-specific competencies" highlighted above, plus three more, namely, "exploitation of target language resources", "provision of accurate explanations", and "ability to improvise" [emphasis added], also drawn from Farrell \& Richards (2007), are recognized by Borg (2001), Chaudron (1998), Edge \& Garton (2009), Ellis (2005), Kim \& Elder (2008), Krashen (1982), McNamara (1991), Naserdeen (2001), Schulz (1999), Scrivener (2005), and Tsui (2003) as essential for effective teaching.

Wondering about the "accent reduction" exercises some of the Panamanian EFL teachers were subjected to during their immersion experience, it is important to underscore that the elusive "native-like" pronunciation is not really needed to be a good EFL teacher; however, obviously, "a minimal proficiency level of pronunciation is required for a future teacher [and student] to be intelligible" (Frazier \& Phillabaum, 2012, p. 172). Intelligibility is the golden rule.

Wright (2009) conducted a study on the development of EFL proficiency of 32 adult, instructed Chinese speakers of English after a ten-month period of immersion in postgraduate studies in UK universities. Her findings suggested that "Immersion helps learners process what linguistic knowledge they already have with greater efficiency, rather than lead to acquisition of new linguistic knowledge" (p. 10). She further indicated that

Some researchers suggest that immersion may not even be necessary to achieve very advanced or native-like levels of proficiency (White \& Juffs 1998). The majority of studies find wide individual variation and fossilisation at advanced levels, even in cases of long-term residence in the L2 environment (see, e.g. Han 2004, Birdsong 2005, Wright 2006, Lardiere 2007). (p.2)

\section{CONCLUSIONS}

All the interviewed teachers deeply appreciated the opportunity they had to stay eight weeks in an English-speaking country under the Panamá Bilingüe program. They believe that they derived specific benefits, in terms of having to use English to communicate, listening to the use of the language by speakers for whom it is their mother tongue; increased awareness of the existence of different varieties of English; enhancement of teaching skills by being exposed to different methods and techniques, practicing some of them in class during their sojourn; language proficiency improvement; metacognitive reflection on their prior knowledge of the language and on their pedagogical practices, becoming aware of strengths and weaknesses; the cultural knowledge, language learning, and joy derived from visiting a different country and places of historical interest in those countries; intercultural contact and new professional relationships; and motivation to keep working toward better student learning outcomes.

The teachers emphasized two disturbing realities that need to be addressed in order to achieve the desired impact and sustainability of efforts to improve English teaching in Panama:

1. The very low English proficiency of many, if not most, primary school EFL teachers in the country. The interviewed teachers thought that an eight-week immersion program would not significantly improve the linguistic skills of most of their primary school EFL colleagues.

2. The inadequate physical conditions in which English teachers perform their work. Thousands of students are expected to learn English in crowded rooms with no air conditioning, in the humid, and often hot, tropical environment. Many peasant children still assemble under thatched or tin-roofed, multigrade classrooms after walking long distances under sun and rain, often crossing dangerous bridges or wading through streams.

A third concern mentioned by some of the teachers was that many aspects of the programs offered by the host universities were designed to meet the needs of teacher learners and students in ESL teaching contexts, far removed from the context of EFL teaching in the public school system of Panama.

In a country where quality education and English language learning have traditionally been accessible only to a minority, Panamá Bilinguie is a laudable initiative, a strong statement for reform and the democratization of English language teaching in the country. The implementation of this program can lead to confirming or discovering what is needed to teach and learn English successfully in Panama, using "an appropriate pedagogy" (Kramsch \& Sullivan, 1996; "an appropriate methodology", said Holliday, 1994), serving local and national needs.

Panama is a small country in close contact with the rest of the world due to its strategic geographical position. The knowledge and use of English with intercultural communicative competence (Sun, 2014) can empower its citizens to develop their personal potential above and beyond current educational inequalities and limitations.

\section{ACKNOWLEDGEMENTS}

The author wishes to thank Quality Leadership University for the invitation to participate in the "Conducting Research in TESOL" seminar-workshop taught by C. de Kleine, of Notre Dame of Maryland University, in Panama in 2016, and for the support provided. 


\section{REFERENCES}

[1] Bame, J. (2001, April). Review of the book Non-Native Educators in English Language Teaching, by G. Braine (Ed.). TESL-EJ, 5(1), R-9. Available online: http://www.tesl-ej.org/ej17/r9.html (accessed 10/10/16).

[2] Barkhuizen, G. (2015). Narrative Inquiry. In B. Paltridge \& A. Phakiti (Eds.), Research Methods in Applied Linguistics: A Practical Resource (pp. 169-185). London: Bloomsbury Publishing Plc.

[3] Borg, S. (2015a). Researching Teachers' Beliefs. In B. Paltridge \& A. Phakiti (Eds.), Research Methods in Applied Linguistics: A Practical Resource (pp. 487-504). London: Bloomsbury Publishing Plc.

[4] Borg, S. (2015b). Researching Language Teacher Education. In B. Paltridge \& A. Phakiti (Eds.), Research Methods in Applied Linguistics: A Practical Resource (pp. 541-560). London: Bloomsbury Publishing Plc.

[5] Braine, G. (2005). A history of research on non-native speaker English teachers. In Llurda, E. (Ed.), Non-Native Language Teachers: Perceptions, Challenges and Contributions to the Profession (pp. 13-23). New York: Springer.

[6] Cullen, R. (1994). Incorporating a language improvement component in teacher training programmes. ELT Journal, 48(2), 162172. doi:10.1093/elt/48.2.162 (accessed 12/5/2016)

[7] Davies, A. (2003). The Native Speaker: Myth and Reality. Clevedon: Cromwell Press Ltd.

[8] EF Education First. (2014). EF English Proficiency Index (3 ${ }^{\text {rd }}$ ed.). Retrieved from EF Education First Ltd.website:http://www.ef.com.pa/_ / /media/efcom/epi/2014/full-reports/ef-epi-2013-report-master.pdf (accessed 5/8/16).

[9] Edge, J. (1988). Natives, speakers, and models. Japan Association of Language Teachers Journal, 9(2), 153-157. Retrieved from JALT Publications website: http://jalt-publications.org/files/pdf/jalt_journal/jj-9.2.pdf\#page=93 (accessed 11/12/16).

[10] Farrell, T. S. C. \& Richards, J. C. (2007). Teachers' language proficiency. In T. S. C. Farrell (Ed.), Reflective Language Teaching: From Research to Practice (pp. 55-66). London: Continuum.

[11] Frazier, S. \& Phillabaum, S. (2012). How TESOL Educators Teach Nonnative English-Speaking Teachers. The CATESOL Journal (23)1, 155-181. Retrieved from http://www.catesoljournal.org/wp-content/uploads/2014/06/CJ23_frazier.pdf (accessed $11 / 15 / 16)$.

[12] Freeman, D. (1989). Teacher Training, Development and Decision Making: A Model of Teaching and Related Strategies for Language Teacher Education. TESOL Quarterly, 23(1), 27-45. doi: 10.2307/3587506 (accessed 10/31/16).

[13] Fulbright Scholar Program, Panama. (n.d., ca. late 2015). Retrieved from http://www.cies.org/sites/default/files/documents/Panama.pdf (accessed 5/23/16).

[14] Government of Panama. Ministry of Education. (2014, July). Gobierno Nacional pone en marcha Programa Panamá Bilingüe [The Government of Panama launches the Panama Bilingüe Program]. Retrieved from the Ministry of Education, Government of Panama, website: http://www.meduca.gob.pa/?n=507 (accessed 5/8/16).

[15] Government of Panama. Ministry of the Presidency. (2016, April 4). Executive Decree 148 of April 1, 2016, Establishing the Panama Bilingüe Program and Regulating its Implementation. Official Digital Gazette No. 28002-A. Retrieved from the Ministry of the Presidency, Government of Panama, website: https://www.gacetaoficial.gob.pa/pdfTemp/28002_A/GacetaNo_28002a_20160404.pdf (accessed 6/12/16).

[16] Harvey, S., Roskvist, A., Corder, D., \& Stacey, K. (2011). An Evaluation of the Language and Culture Immersion Experiences (LCIE) for Teachers Programmes: Their impact on teachers and their contribution to effective second language learning. Report prepared for the New Zealand Ministry of Education. Retrieved from https://www.aut.ac.nz/profiles/sharonharvey/?a=279263 (accessed 6/10/16).

[17] Holliday, A. (1994). Appropriate Methodology and Social Context. Cambridge: Cambridge University Press.

[18] Holliday, A. (2014, December 12). What is behind the "native speaker" and "non-native speaker" labels [Blog post]. Retrieved from http://adrianholliday.com/what-is-behind-the-native-speaker-and-non-native-speaker-labels/ (accessed 11/13/16).

[19] Holliday, A. (2015). Qualitative Research and Analysis. In B. Paltridge \& A. Phakiti (Eds.), Research Methods in Applied Linguistics: A Practical Resource (pp. 49-61). London: Bloomsbury Publishing Plc.

[20] Johnson, K. E. \& Golombek, P. R. (2011). The transformative power of narrative in second language teacher education. TESOL Quarterly, 45(3), 486-509. doi:10.5054/tq.2011.256797 (accessed 10/23/16).

[21] Johnson, R. K. \& Swain, M. (Eds.). (1997). Immersion Education: International Perspectives. Cambridge: Cambridge University Press.

[22] Kramsch, C., \& Sullivan, P. (1996). Appropriate pedagogy. ELT Journal, 50(3), 199-212. doi:10.1093/elt/50.3.199 (accessed 12/5/16).

[23] Kumaravadivelu, B. (2001). Toward a postmethod pedagogy. TESOL Quarterly, 35(4), 537-560. doi:10.2307/3588427 Retrieved http://www.bkumaravadivelu.com/articles\%20in\%20pdfs/2001\%20Kumaravadivelu\%20Postmethod\%20Pedagogy.pdf (accessed 1/28/17).

[24] Lee, J. F. K. (2009). ESL student teachers' perceptions of a short-term overseas immersion programme. Teaching and Teacher Education, 25(8), 1095-1104.doi:10.1016/j.tate.2009.03.004 (accessed 10/20/16).

[25] Liu, D. (1999). Training non-native TESOL students: Challenges for TESOL teacher education in the West. Chapter 13 in G. Braine (Ed.), Non-Native Educators in English Language Teaching (pp. 197-210). Mahwah, NJ: Lawrence Erlbaum.

[26] McKay, S. L. (2003). Toward an appropriate EIL pedagogy: Re-examining common ELT assumptions. International Journal of Applied Linguistics, 13(1), 1-22. doi: 10.1111/1473-4192.00035 (accessed 11/16/16).

[27] Medgyes, P. (1999). Language training: A neglected area in teacher education. In Braine, G. (Ed.), Non-Native Educators in English Language Teaching (pp. 177-196). Mahwah, NJ: Lawrence Erlbaum.

[28] Murdoch, G. (1994). Language development provision in teacher training curricula. ELT Journal 48(3), 253-265. doi:10.1093/elt/48.3.253 (accessed 12/5/2016).

[29] Paikeday, T. M. (1985). The native speaker is dead! Toronto: Paikeday Publishing, Inc

[30] Phakiti, A. \& Paltridge, B. (2015). Approaches and Methods in Applied Linguistics Research. In B. Paltridge \& A. Phakiti (Eds.), Research Methods in Applied Linguistics: A Practical Resource (pp. 5-25). London: Bloomsbury Publishing Plc. 
[31] Phillipson, R. (1992). Linguistic imperialism. Oxford: Oxford University Press.

[32] Reeves, T. \& Medgyes, P. (1994). The non-native English speaking EFL/ESL teacher's self-image: An international survey. System, 22(3), 353-367. Available from ScienceDirect data base: http://www.sciencedirect.com/science/article/pii/0346251X9490 (accessed 10/15/16).

[33] Richards, H., Conway, C., Roskvist, A., \& Harvey, S. (2013). Foreign Language Teachers' Language Proficiency and Their Language Teaching Practice. The Language Learning Journal, 41(2), 231-246. doi: 10.1080/09571736.2012.707676 (accessed $11 / 21 / 16)$.

[34] Richards, J. C. (2011). Exploring teacher competence in language teaching. The Language Teacher Online, 35(4), 3-7. Retrieved from Publications of the Japan Association for Language Teaching website: jalt-publications.org/files/pdfarticle/plen1.pdf (accessed 11/20/16).

[35] Roskvist, A., Harvey, S., Corder, D., \& Stacey, K. (2014). "To improve language, you have to mix": Teachers' perceptions of language learning in an overseas immersion environment. The Language Learning Journal, 42(3), 321-333. Available from http://dx.doi.org/10.1080/09571736.2013.785582 (accessed 11/16/16).

[36] Shin, H. (2007). English Language Teaching in Korea: Toward Globalization or Glocalization? Chapter 6 in J. Cummins \& C. Davison (Eds.), International Handbook of English Language Teaching (pp. 75-86). New York: Springer.

[37] Sun, Y. (2014, December 15). What is Intercultural Communicative Competence? [Blog post]. Retrieved from http://blog.tesol.org/what-is-intercultural-communicative-competence/ (accessed 12/16/16).

[38] Swain, M. \& Lapkin, S. (2005). The evolving sociopolitical context of immersion education in Canada: Some implications for program development. International Journal of Applied Linguistics, 15(2), 169-186. doi: 10.1111/j.1473-4192.2005.00086.x (accessed 10/15/16).

[39] Swan, A., Aboshiha, P. \& Holliday, A. (Eds.). (2015). (En) Countering Native-speakerism: Global Perspectives. Basingstoke, England: Palgrave Macmillan.

[40] United Nations, Panama. Erradicar la pobreza y el hambre [Erradicating poverty and hunger]. (2016). Retrieved from http://www.onu.org.pa/objetivos-desarrollo-milenio-ODM/erradicar-pobreza-extrema-hambre (accessed 6/5/2016).

[41] U.S. Department of State. (2015-2016). Fellow Projects from Panama - English Language Programs. Retrieved from https://elprograms.org/projects/panama-city_panama_ministry-of-education_2015-2016-2/(accessed 5/30/16).

[42] U.S. Embassy, Panama. (2014, August 28). English Teacher Match for Panama. Retrieved from http://panama.usembassy.gov/ni082814.html (accessed 5/15/16).

[43] U.S. Embassy, Panama. (2015, ca. September 18). Remarks by Kristin Stewart, Public Affairs Officer, U.S. Embassy, TESOL Panama 2015. Retrieved from http://panama.usembassy.gov/sp091815.html (accessed 5/15/16).

[44] Wang, D. (2014). Effects of Study Abroad on Teachers' Self-perceptions: A Study of Chinese EFL Teachers. Journal of Language Teaching and Research, 5(1), 70-79. doi: 10.4304/jltr.5.1.70-79 Retrieved from http://www.academypublication.com/issues/past/jltr/vol05/01/09.pdf (accessed 10/14/16).

[45] Wright, C. (2009). "I still can't questions": Issues affecting EFL development in an immersion environment. Novitas-ROYAL, 3(1), 1-13. Retrieved from http://www.novitasroyal.org/Vol_3_1/wright.pdf (accessed 11/29/16).

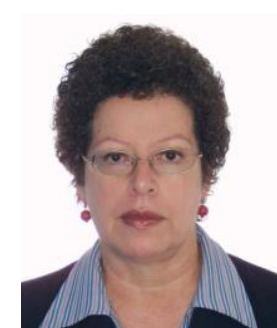

Dalys Vargas was born in Panama, Republic of Panama, in 1952. Received primary education in English in U.S. Government schools in the former Canal Zone, Panama, graduating with honors from Balboa High School in 1970. BA in International Relations, University of Panama, 2004. Earned MA-TESOL degree in 2009, in a dual degree program offered in Panama by Quality Leadership University and College of Notre Dame of Maryland, later renamed Notre Dame of Maryland University.

She is a Certified Public Translator from Spanish to English and vice versa since 1993, and an English teacher in the English for Professional Success evening program for adults offered by Quality Leadership University and the University of Louisville, Panama Campus. From September, 2011 to February, 2014, she was Director of Cooperation and International Relations, Universidad Especializada de las Américas (UDELAS), a public university in Albrook, Republic of Panama. She currently works as an Executive Assistant at the Ministry of Foreign Affairs of the Republic of Panama. 